\title{
KESIAPAN MADRASAH DALAM PEMENUHAN STANDAR LAYANAN MINIMAL PENDIDIKAN
}

\author{
Umul Hidayati
}

\begin{abstract}
The results of this research indicate that Islamic schools' preparedness in attaining the minimum education service standards (educators and education personnel according to Education National Standards) is categorized as fair. However, the Islamic schools' preparedness has not either reached ideal condition or maximum level as there are still weaknesses found in several components in terms of educators/teachers, Islamic school principals or supervisors. Teacher competence (at Islamic Elementary School and Islamic Junior High School) is categorized as fair with an average score of 3.9; school principal competence (at Islamic Elementary School and Islamic Junior High School) is categorized as fair with an average score of 3.8; meanwhile, supervisor competence is categorized as fair with an average score of 3.6 .
\end{abstract}

Keywords: Preparedness, attainment, minimum service standards, educators, education personnel.

Dra. Umul Hidayati adalah Peneliti pada Puslitbang Pendidikan Agama dan Keagamaan Badan Litbang dan Diklat Departemen Agama RI

\section{PENDAHULUAN}

\section{A. Latar Belakang}

Salah satu faktor penentu keberhasilan penyelenggaraan pendidikan di madrasah adalah terpenuhinya aspek pendidik dan tenaga kependidikan yang memadai baik secara kualitas maupun kuantitas. Secara kualitas, terpenuhinya standar kompetensi dan kualifikasi pendidik dan tenaga kependidikan madrasah. Sedangkan secara kuantitas, terpenuhinya jumlah pendidik dan tenaga kependidikan 
tersebut mencapai kondisi ideal dalam menunjang kegiatan belajar mengajar. Pendidik di madrasah, sesuai pasal 28 SNP adalah para guru yang mengajar di madrasah.

Data Emis tahun 2006 menunjukkan bahwa jumlah guru MI sebanyak 195.898 orang, yang berpendidikan D.4 dan S.1 keatas sekitar 15,78\%. Sementara jumlah guru MTs sebanyak 215.193 orang, yang berpendidikan S.1 dan D.4 keatas sekitar 52,64\%. Sedangkan kepala madrasah sebanyak 22.610 orang, yang berpendidikan S.1 keatas sekitar 30,06\% dan kepala MTs sebanyak 12.499 orang, yang berpendidikan $\mathrm{S} .1$ keatas sekitar $66,03 \%$. Jumlah pengawas sebanyak 7.060 orang, yang berpendidikan S.1 keatas sekitar 65,84\%. ${ }^{1}$

Data tersebut menggambarkan bahwa kondisi pendidik dan tenaga kependidikan madrasah masih belum memadai baik secara kualitas maupun kuantitas. Secara kualitas masih banyak guru dan kepala madrasah serta pengawas yang berpendidikan di bawah S.1 atau D4. Dari segi kompetensi, masih banyak guru yang mengajar tidak sesuai dengan bidang tugasnya atau mismatch.

Untuk dapat meningkatkan kualitas pendidik dan tenaga kependidikan, Departemen Agama telah melakukan berbagai upaya antara lain melalui diklat kependidikan dan studi lanjutan, yang dimulai tahun 1994 melalui dana ADB (Asian Development Bank) dan tahun 1997 melalui DMAP (Development Madrasab Aliyab Project). ${ }^{2}$ Tahun 2006, Departemen Agama kembali menyekolahkan pendidik dan tenaga kependidikan sebanyak 675 orang ${ }^{3}$ dan tahun 2007 sebanyak 1.325 orang ke program (S-2) pada $15 \mathrm{PTN}^{4}$ Sementara untuk meningkatkan kuantitas

1 Data Statistik Pendidikan Agama dan Keagamaan, Tahun 2006, Direktorat Jenderal Pendidikan Islam Departemen Agama

2 Sebanyak 18 orang kuliah di luar negeri (6 orang kuliah di Canada dan 12 orang di US) dan sebanyak 346 orang kuliah di dalam ngeri (30 orang kuliah di Universitas Negeri Jakarta, 30 orang di Universitas Makasar, 30 orang di Universitas Negeri Padang dan 250 orang di Universitas Pendidikan Indonesia Bandung).

${ }^{3}$ Rincian dari 675 orang itu adalah : 60 guru PAl pada SMP, 60 guru PAI pada MTs, 30 guru Bahasa Arab pada MTs, 30 guru Bahasa Inggris pada MTs, 30 guru Matematika pada MTs, 30 guru IPA/Biologi pada MTs, 30 guru IPA/Fisika pada MTs, 30 guru PAl pada SMA, 60 guru PAl pada MA, 30 guru Bahasa Arab pada MA, 30 guru Bahasa Inggris pada MA, 30 guru Matematika pada MA, 60 guru Kimia pada MA, 30 guru Fisika pada MA, 30 guru Biologi pada MA, 35 pegawai Evaluasi/psikometri (guru), 35 pegawai Kurikulum, 35 pengawas.

${ }^{4}$ Suara Merdeka, Selasa 21 Agustus 2007, "Atasi Ketertinggalan Madrasah, 2000 Guru Madrasah dapat Beasiswa." 
pendidik dan tenaga kependidikan, menambah jumlah ketenagaan melalui rekrutmen CPNS, guru bantu, pengangkatan guru dan tenaga honorer.

Dalam upaya meningkatkan mutu pendidikan, pemerintah telah mengeluarkan PP No.19 tahun 2005 tentang SNP yang bertujuan untuk menjamin mutu pendidikan nasional guna mencerdaskan kehidupan bangsa. Adapun fungsinya adalah sebagai dasar dalam perencanaan, pelaksanaan dan pengawasan pendidikan dalam rangka mewujudkan pendidikan nasional yang bermutu.

Saat ini, diduga masih banyak pendidik dan tenaga kependidikan (MI dan MTs) belum memenuhi atau bahkan berada di bawah SNP. Untuk mengetahui kondisi pendidik dan tenaga kependidikan madrasah (MI dan MTs) lebih mendalam, pada tahun ini puslitbang Pendidikan Agama dan Keagamaan melakukan penelitian tentang hal tersebut. Penelitian ini menjadi penting, mengingat penelitian dengan tema yang sejenis belum pernah dilakukan.

Secara umum tujuan penelitian adalah untuk mengetahui kesiapan madrasah dalam pemenuhan standar layanan minimal pendidikan. Sedangkan secara khusus untuk melihat kesiapan pendidik dan tenaga kependidikan MI dan MTs menurut SNP. Penelitian ini dilakukan dengan menggunakan metode survai yaitu data dikumpulkan dari sejumlah sampel/populasi untuk mewakili seluruh populasi yang ada. ${ }^{5}$ Pengumpulan data dilakukan dengan menggunakan metode kuantitatif dan dibantu dengan kualitatif. Metode kualitatif untuk memperoleh data kualitatif guna memperdalam hasil deskripsi data kuantitatif.

Penelitian dilaksanakan di enam propinsi yaitu di Propinsi Sumbar, Sumsel, Jabar, DIY, Jatim dan Kalbar. Populasi penelitian adalah pendidik dan tenaga kependidikan terdiri dari guru, kepala dan pengawas yang ada di 6 propinsi daerah sasaran penelitian. Lembaga pendidikan yang menjadi sasaran penelitian adalah MI dan MTs baik yang berstatus negeri maupun swasta dengan perimbangan $33 \%$ negeri dan $66 \%$ swasta. Jumlah madrasah sasaran sebanyak $9 \mathrm{MI}$ dan $6 \mathrm{MTs}$, Sedangkan responden sebanyak 60 orang guru, 15 orang kepala madrasah dan 5 orang pengawas untuk masing-masing daerah.

Pengumpulan data dilakukan menggunakan instrumen penelitian yang terdiri dari : 1) angket, 2) daftar isian, 3) pedoman wawancara,

${ }^{5}$ Wina Sanjaya. 2005. Pembelajaran dalam Implementasi Kurikulum Berbasis Kompetensi. Jakarta: : Prenada Media, hh. 142-143. 
4) dokumentasi. Analisa data dilakukan dengan teknik analisis kuantitatif, yang dilanjutkan dengan penafsiran kualitatif. Data yang bersifat kuantitatif dianalisis dengan menggunakan teknik statistik deskriptif, sedangkan data kualitatif diolah dengan teknik analisis kuantitatif dan ditafsirkan secara kualitatif. Sebagai pedoman menyimpulkan hasil penelitian dilakukan pengkategorian sebagai berikut:

Pedoman Klasifikasi Penilaian

\begin{tabular}{|c|c|c|c|c|}
\hline No & Rentang Nilai (\%) & Kualifikasi & Kategori jawaban & Keterangan \\
\hline 1 & $90-100$ & A & SL & Sangat Siap \\
\hline 2 & $80-89$ & B & SR & Siap \\
\hline 3 & $65-79$ & C & KD & Cukup siap \\
\hline 4 & $55-64$ & D & JR & Kurang siap \\
\hline 5 & $0-54$ & E & TP & Sangat kurang siap \\
\hline
\end{tabular}

\section{B. Kerangka Teori}

\section{Kesiapan madrasah}

Terkait dengan judul penelitian yang akan melakukan analisis kesiapan madrasah dalam pemenuhan standar layanan minimal pendidikan (standar pendidik dan tenaga kependidikan menuruut SNP), maka kesiapan madkasah yang akan dilihat dalam penelitian adalah kesiapan pendidik dan tenaga kependidikan yang meliputi kesiapan profesional, kesiapan psikologis kultural dan kesiapan manajerial.

a. Kesiapan Profesional

Kesiapan profesional, maksudnya adalah profesional sebagai pendidik dan tenaga kependididkan sesuai dengan SNP. Profesional adalah pekerjaan yang dilakukan oleh seseorang yang memerlukan keahlian, kemahiran dan kecakapan yang memenuhi standar mutu tertentu. Oleh karena itu pekerjaan yang profesional harus ditunjang : 1) ilmu yang mendalam yang didapat dari lembaga pendidikan yang sesuai; 2) keahlian yang spesiffk sesuai dengan bidang profesinya; 3) latar belakang pendidikan yang diakui oleh masyarakat, sehingga semakin tinggi latar pendidikannya semakin tinggi pula tingkat keahliannya. ${ }^{6}$ Jika dijabarkan lebih lanjut, maka untuk menjadi guru profesional, minimal harus

\footnotetext{
${ }^{6}$ Mukhlas Samani dkk. 2006. Sertifikasi Guru di Indonesia. Surabaya: SIC.
} 
memenuhi tiga persyaratan yaitu kualifikasi pendidikan minimum, kompetensi dan sertifikasi pendidik. ${ }^{7}$

b. Kesiapan Psikologis kultural

Kesiapan psikologis kultural adalah adanya budaya atau kebiasaankebiasaan yang dibangun madrasah yang secara psikologis berpengaruh terhadap peningkatan profesionalitas pendidik dan tenaga kependidikan. Budaya madrasah adalah keseluruhan latar fisik, lingkungan, sarana prasarana, sifat dan iklim yang secara produktif mampu memberikan pengalaman dan dorongan kepada pendidik dan tenaga kependidikan untuk meningkatkan profesionalitasnya. ${ }^{8}$ Sementara madrasah merupakan sebuah organisasi, sehingga budaya madrasah juga merupakan budaya organisasi. Menurut Winardi, sebuah organisasi formal memiliki struktur yang terumuskan dengan baik, yang menerangkan adanya hubungan otoritas, kekuasaan, akuntabilitas dan tanggungjawab.' Dari uraian ini maka yang dimaksud budaya organisasi madrasah adalah kebiasaankebiasaan yang sudah dibangun untuk meningkatkan profesionalitas pendidik dan tenaga kependidikan guna memenubi SNP.

\section{c. Kesiapan Manajerial}

Kesiapan manajerial, maksudnya adalah kesiapan secara manajerial dalam melakukan kepemimpinan madrasah. Menurut Malayu, manajemen adalah ilmu dan seni mengatur proses pemanfaatan sumberdaya manusia dan sumber-sumber daya lainnya secara efektif dan efisien untuk mencapai tujuan tertentu. Dengan demikian, kesiapan manajerial adalah kesiapan dalam melakukan kepemimpinan madrasah untuk mengatur atau mengelola sumberdaya madrasah guna menunjang peningkatan profesionalitas pendidik dan tenaga kependidikan untuk dapat mencapai SNP.

${ }^{7}$ Laporan Penelitian Puslitbang Pendidikan Agama dan Keagamaan tahun 2007 berjudul "Pengembangan Budaya Sekolah Dalam Meningkatkan Mutu Pendidikan (Studi.Tentang Pengaruh Budaya Sekolah, Motivasi Belajar Terhadap Mutu Pendidikan Agama Islam), h. 15

\$Winardi. 2003. Teori Organisasi dan Pengorganisasian. Jakarta: PT. Rajagrafindo Persada, h. 9.

9 Cece Wijaya dan Rusyan A. Tabrani. 1994. Kemampuan Dasar Guru Dalam Proses Belajar Mengajar. Bandung: PT. Remaja Rosdakarya, hh. 36-37. 


\section{Standar Pendidik dan Tenaga Kependidikan}

a. Standar Pendidik

Pendidik menurut penjelasan pasal 28 ayat 1 SNP adalah tenaga kependidikan yang berkualifikasi dan berkompetensi sebagai guru, dosen, konselor, tutor, pamong belajar, widyaiswara, fasilitator yang berpartisipasi dalam penyelenggaraan pendidikan. Menurut pasal 39 ayat 2 UU No. 20 tahun 2003 Sisdiknas adalah tenaga profesional yang bertugas merencanakan dan melaksanakan proses pembelajaran, menilai hasil pembelajaran serta melakukan penelitian dan pengabdian kepada masyarakat. Adapun dalam UU RI No. 14 tahun 2005 tentang guru dan dosen bab I pasal 1, adalah tenaga professional dengan tugas utama mendidik, mengajar, membimbing, mengarahkan, melatih, menilai dan mengevaluasi peserta didik pada pendidikan usia dini, pendidikan dasar dan menengah.

Dilihat dari fungsinya, pendidik memiliki lima fungsi yaitu: 1) sebagai pendidik dan pengajar, 2) sebagai anggota masyarakat, 3) sebagai pemimpin, 4) sebagai pelaksana administrasi dan 5) sebagai pengelola proses belajar mengajar. ${ }^{10}$ Sedangkan dilihat dari bidang tugasnya, memiliki tiga jenis tugas yaitu : 1) tugas dalam bidang profesi, 2) bidang kemanusiaan dan 3) bidang kemasyarakatan. ${ }^{11}$

Dalam pasal 28 ayat 1 SNP, pendidik harus memiliki kualifikasi akademik dan kompetensi sebagai agen pembelajaran, sehat jasmani dan tohani, serta memiliki kemampuan untuk mewujudkan tujuan pendidikan nasional. Kualifikasi pendidik menurut pasal 29 ayat 2 dan 3 adalah: 1)berpendidikan minimal D.4 atau S.1; 2) latar belakang pendidikan tinggi di bidang pendidikan SD/MI; 3)bersertifikasi profesi guru SD/MI. Sedangkan kualifikasi pendidik pada SMP/MTs adalah : 1) berpendidikan D.4 atau S.1;2) latar belakang pendidikan tinggi dengan program pendidikan yang sesuai dengan mata pelajaran yang diajarkan; 3) sertifikasi profesi guru untuk SMP/MTs. Sedangkan kompetensi pendidik dijelaskan dalam UU No. 14 tahun 2005 tentang guru dan dosen, dalam PP No. 19 tahun 2005 tentang SNP dan dalam

\footnotetext{
${ }^{10}$ Moh. Uzer Usman. 1995. Menjadi Guru Profesional. Bandung: PT. Remája Rosdakarya, h. 6.

$"$ E. Mulyasa. 2004. Kurikulum Berbasis Kompetensi (Konsep, Karakteristik dan Implementasi). Bandung: Remaja Rosdakarya, h. 37.
} 
Permendiknas No. 16 tahun 2007 tentang standar kualifikasi dan kompetensi guru, bahwa kompetensi pendidik meliputi kompetensi paedagodik; kompetensi kepribadian; kompetensi sosial; kompetensi profesional.

Menurut Mulyasa, kompetensi adalah merupakan perpaduan dari pengetahuan, keterampilan, nilai, sikap yang direfleksikan dalam kebiasaan berpikir dan bertindak. ${ }^{12}$ Sedangkan MC.Ashan (1981:45) menyebutkan bahwa kompetensi merupakan pengetahuan, keterampilan dan kemampuan yang dikuasai oleh seseorang yang telah menjadi bagian dari dirinya, sehingga ia dapat melakukan perilaku kognitif, afektif dan psikomotor dengan baik. ${ }^{13}$ Menurut Hornby, kompetensi merupakan keterampilan, kekuasaan, kewenangan, dan pengetahuan yang diperlukan untuk melaksanakan tugas tertentu. ${ }^{14}$

\section{b. Tenaga Kependidikan}

Tenaga kependidikan ini dibatasi pada kepala madrasah dan pengawas, karena baru kedua tenaga kependidikan tersebut yang telah memiliki standar sesuai SNP dan telah diatur dalam Permendiknas No 13 tahun 2007 untuk Standar Kepala Madrasah dan No 12 tahun 2007 untuk Standar Pengawas Madrasah. Terkait dengan standar tenaga kependidikan, maka yang dilihat meliputi kualifikasi dan kompetensinya.

Dalam pasal 38 SNP dan Permendiknas Nomor 13 tahun 2007 disebutkan bahwa kualifikasi kepala madrasah jenjang SD/MI dan SMP/MTs terdiri atas kualifikasi umum dan kualifikasi khusus. Kualifikasi umum meliputi : a) jenjang pendidikan S1 atau D.4; b) pada waktu diangkat menjadi kepala berusia minimal berusia 56 tahun; c) memiliki pengalaman mengajar minimal lima tahun; d) memiliki pangkat minimal III/c sebagai PNS dan non PNS disetarakan dengan kepangkatan yang dikeluarkan yayasan atau lembaga yang berwenang. Kualifikasi khusus meliput : a) berstatus sebagai guru SD/MI dan SMP/MTs; b) memiliki sertipikat guru SD/MI dan SMP/MTs; c) memiliki sertipikat kepala SD/MI dan SMP/MTs. Sedangkan kompetensi kepala menurut pasal

12 Jatmiko Wibowo, Alexander dan Fandi Tjiptono. 2002. Pendidikan Berbasis Kompetensi. Yogya karta: Universitas Atmajaya, h. 85-86.

13 AS. Hornby. 1982. Dictionary of Current English. Oxford University Press, h. 172.

${ }^{14} \mathrm{M}$. Ngalim Purwito. 2005. Dalam Puslitbang Pendidikan Agama dan Keagamaan, Kinerja Pengawas Pendidikan Agama Islam, h. 19. 
38 SNP dan Permendiknas Nomor 13 tahun 2007, meliputi kompetensi kepribadian, manajerial, kewirausahaan, supervisi dan sosial.

Pengawas menurut Keputusan Menpan No. 118/1996 yang ditetapkan melalui. Keputusan Menag No. 381 tahun 1999, adalah PNS yang diberi tugas dan tanggung jawab untuk melakukan pengawasan di madrasah, dengan melakukan penilaian, pembinaan teknis dan administrasi pada Satuan Pendidikan Prasekolah, Pendidikan Dasar dan Menengah. Oleh karena itu pengawasan adalah suatu aktifitas pembinaan yang direncanakan untuk membantu para guru dan pegawai lainnya dalam pekerjaan mereka secara efektif. ${ }^{15}$

Syarat menjadi pengawas menurut Permendiknas Nomor 12 tahun 2007 yaitu harus memiliki kualifikasi akademik yang terdiri atas kualifikasi umum dan khusus. Kualifikasi umum pengawas SD/MI dan SMP/MTs meliputi pangkat minimal III/c; berusia maksimal 50 tahun pada waktu diangkat sebagai pengawas; lulus seleksi pengawas; menempuh pendidikan profesi pengawas; mengikuti uji kompetensi. Adapun kalifikasi khusus meliputi pendidikan minimal S.1; pengalaman menjadi Kepala SD/MI minimal 4 tahun dan kualifikasi khusus pengawas SMP/MTs meliputi pendidikan minimal S.2 dengan berbasis S.1 kependidikan atau S.1 non-kependidikan plus akta dalam rumpun mata pelajaran yang relevan; bersertifikat guru SMP/MTs dan pengalaman kerja minimal 8 tahun atau kepala SMP/MTs berpengalaman kerja minimal 4 tahun. Sedangkan kompetensi pengawas meliputi kompetensi kepribadian, supervisi manajerial, supervisi akademik, evaluasi pendidikan, penelitian pengembangan dan kompetensi sosial.

\section{HASIL PENELITIAN DAN PEMBAHASAN}

\section{A. Deskripsi Kesiapan Guru Madrasah Menurut SNP}

Dilihat dari kesiapannya, secara umum guru madrasah (MI dan MTs) telah memimiliki kesiapan dalam pemenuhan standar layanan minimal pendidikan, namun kesiapan yang dimiliki tersebut belum mencapai kondisi ideal atau maksimal, karena masih banyak pendidik dan tenaga kependidikan baik dilihat dari kualifikasi dan kompetensinya berada di bawah standar nasional pendidikan (SNP).

1. Kualifikasi Guru Madrasah (MI dan MTs)

Dilihat dari kualifikasinya, hasil penelitian menunjukkan bahwa sekitar $60 \%$ guru berpendidikan S.1;24,9\% berpendidikan diploma; 
11,1 \% berpendidikan SLA dan 1,7 \% berpendidikan SLTP. Ini berarti bahwa guru yang berpendidikan di bawah $\mathrm{S} 1$ jumlahnya masih cukup banyak yakni sekitar $40 \%$. Temuan penelitian ini menggambarkan bahwa kondisi guru madrasah (MI dan MTs) belum ideal memenuhi standar kualifikasi guru sesuai SNP dilihat dari jenjang pendidikan formal. Guru yang berpendidikan SLTA dan SLTP ini umumnya merupakan guru yang mengajar di madrasah swasta dan sebagian besar merupakan guru agama. Mereka berasal dari alumni pondok pesantren. Sedangkan dilihat dari segi keikutsertaannya dalam diklat pendidikan, hasil penelitian menunjukkan bahwa sekitar $50 \%$ guru pernah mengikuti diklat kependidikan yang diadakan oleh Depag, Diknas, Pemda maupun oleh LSM dan lembaga swasta lainnya. Adapun dilihat dari keahlian khusus yang dimiliki guru, baru sekitar $16.8 \%$ guru yang memiliki keahlian khusus tersebut

Masih banyaknya guru yang belum mengikuti diklat kependidikan, menggambarkan bahwa sebenarnya upaya pemerintah untuk meningkatkan kompetensi guru melalui diklat belum merata, sehingga masih banyak guru belum memenuhi standar kompetensi sesuai SNP. Akibatnya banyak guru yang tidak memiliki keahlian spesifi keperti (keahlian berbahasa asing, memanfaatkan sarana prasarana penunjang pembelajaran, keahlian mengembangkan metodologi pembelajaran dsb ) yang sangat berguna untuk menunjang tugasnya dalam mengajar. Sedangkan banyaknya guru yang belum memenuhi standar kualifikasi menurut SNP, terjadi karena proses rekrutmen yang kurang selektif. Madrasah-madrasah swasta terutama yang dibawah pengelolaan satu yayasan dengan pondok pesantren; rekrutmen ketenagaan seringkali dilakukan berdasarkan sistem kekerabatan dan kurang memperhatikan aspek kualifikasi dan kompetensi yang dimiliki calon guru.

2. Kompetensi Guru (MI dan MTs)

Dilihat dari kompetensinya, hasil penelitian menunjukkan bahwa kompetensi guru masuk kategori cukup dengan rerata skor mencapai 3.9. Ini berarti bahwa kompetensi guru (MI dan MTs) telah memenuhi SNP namun belum mencapai kondisi ideal sesuai SNP.

\section{a. Kompetensi Paedagogik dan Wawasan Kependidikan Guru (MI dan MTs)}

Dilihat dari kompetensi paedagogiknya, hasil penelitian menunjukkan bahwa guru masuk kategori cukup dengan rerata skor mencapi 3.8 . Hasil ini menggambarkan bahwa meskipun kompetensi paedagogik 
guru telah memenuhi SNP namun belum mencapai kondisi ideal. Beberapa indikator yang telah memenuhi konpetensi adalah kemampuan guru dalam mempersiapkan rencana pembelajaran dan menyusun materi ajar, memahami berbagai peraturan kebijakan kependidikan, memberikan pemahaman dan motivasi kepada peserta didik, mempelajari konsep kepribadian dan perilaku serta perkembangan siswa. Adapun beberapa indikator yang belum memenuhi kompetensi adalah kemampuan guru dalam mengembangkan landasan budaya madrasah dan kerangka dasar kurikulum, menggunakan metode pembelajaran sesuai materi ajar, melakukan kerjasama untuk meningkatkan inovasi pembelajaran, melakukan evaluasi serta memanfaatkan hasilnya untuk perbaikan.

\section{b. Kompetensi Profesional Guru (MI dan MTs)}

Dilihat dari kompetensi profesionalnya, hasil penelitian menunjukkan bahwa kompetensi profesional guru masuk kategori kurang dengan rerata skor mencapi 3.2. Hasil ini menunjukkan bahwa kompetensi profesional guru madrasah belum memenuhi SNP. Beberapa indikator yang belum memenuhi kompetensi profesional guru adalah kemampuan guru dalam mengaitkan materi ajar dengan perkembangan IPTEK; menggunakan media penyaji berupa audio visual dan menggunakan media interaktif berupa komputer, multimedia, LCD dsb dalam mengajar.

c. Kompetensi Sosial Guru Madrasab (MI dan MTs)

Dilihat dari kompetensi sosialnya, hasil penelitian menunjukkan bahwa kompetensi sosial guru madrasah masuk kategori baik dengan rerata skor mencapi 4.0. Hasil ini menunjukkan bahwa kompetensi sosial guru madrasah telah sesuai dengan SNP. Beberapa Indikator yang mencapai kategori baik adalah kemampuan guru dalam mambangun komunikasi efektif dalam pergaulan, menciptakan komunikasi yang baik dengan peserta didik, membangun kerjasama dengan kepala, guru dan karyawan madrasah dalam melaksanakan tugas, ringan tangan dan memberikan pertolongan bagi yang membutuhkan.

\section{d). Kompetensi Kepribadian Guru (MI dan MTs)}

Kompetensi kepribadian adalah kemampuan kepribadian yang mantap dan stabil yang dimiliki guru madrasah. Indikator-indikator kompetensi tersebut adalah berakhlak mulia, arif dan bijaksana, berwibawa serta dapat menjadi teladan bagi peserta didik, mampu mengevaluasi kinerja sendiri dan mengembangkan diri secara berkelanjutan. Hasil 
penelitian terhadap hal tersebut menunjukkan bahwa kompetensi kepribadian guru madrasah masuk kategori sangat baik dengan rerata skor mencapi 4.5. Hasil ini menunjukkan bahwa kompetensi kribadian guru telah memenuhi SNP dan telah mencapai kondisi ideal.

\section{B. Deskripsi Kesiapan Kepala Madrasah Menurut SNP}

Kesiapan kepala madrasah disini adalah kesiapan sesuai dengan Permendiknas No. 13 tahun 2007 bahwa kepala madrasah harus memiliki kualifikasi dan kompetensi memadai.

1. Kualifikasi Kepala Madrasah (MI dan MTs)

Dilihat dari kualifikasinya, hasil penelitian menunjukkan bahwa kepala madrasah (MI dan MTs) telab memenubi SNP. Dari tujuh indikator yang meliputi kepangkatan dan golongan; usia saat diangkat jadi kepala; pengalaman menjadi guru; jenjang pendidikan, sertifikasi keguruan; sertifikasi kepala madrasah dan diklat profesional, lima diantaranya yaitu pangkat dan golongan; usia; jenjang pendidikan dan diklat profesi yang pernah diikuti, dua indikator diantaranya yaitu sertifikasi baik sertifikasi keguruan maupun sertifikasi kepala belum memenubi kualifikasi; karena masih sekitar $77.5 \%$ kepala belum tersertifikasi.

2. Kompetensi Kepala Madrasah (MI dan MTs)

Sesuai pasal 38 SNP dan Permendiknas Nomor 13 tahun 2007, kompetensi kepala madrasah meliputi kompetensi kepribadian; manajerial; kewirausahaan; supervisi dan sosial. Ini dilakukan sesuai dengan pasal 38 SNP dan Permendiknas Nomor 13 tahun 2007. Hasil penelitian terhadap kompetensi kepribadian kepala madrasah adalah sebagai berikut.

\section{a. Kompetensi Kepribadian Kepala Madrasah (MI dan MTs)}

Dari hasil penelitian diketahui bahwa kompetensi kepribadian kepala madrasah masuk kategori baik dengan rerata skor mencapi 4.4 . Hasil ini menunjukkan bahwa kompetensi kepribadian kepala madrasah telah memenuhi SNP bahkan telah mencapai kondisi ideal. Dari sembilan indikator kompetensi, seluruhnyatelah mencapai kategori baik, bahkan beberapa aspek mencapai kategori sangat baik.

\section{b. Kompetensi Kewirausahaan Kepala Madrasab (MI dan MTs)}

Kompetensi kewirausahaan adalah segenap kemampuan untuk melakukan usaha pengembangan madrasah yang meliputi kemampuan 
menciptakan inovasi pengembangan madrasah; bekerja keras untuk mencapai keberhasilan madrasah; memiliki motivasi kuat untuk sukses; pantang menyerah dan selalu mencari solusi terbaik dalam menghadapi persoalan; memiliki naluri kewirausahaan dalam pengelolaan madrasah. Melalui beberapa indikator tersebut, hasil penelitian menunjukkan bahwa kompetensi kewirausahaan kepala madrasah masuk kategori baik dengan rerata skor mencapi 3.8. Hasil ini menggambarkan bahwa kompetensi kewitrausahaan yang dimiliki kepala madrasah telah memenuhi SNP namun belum mencapai kondisi ideal sesuai standar kompetensi kepala madrasah.

c. Kompetensi Supervisis Kepala Madrasab (MI dan MTs)

Kompetensi supervisi adalah segenap kemampuan kepala madrasah dalam melakukan supervisi atau bimbingan kepada seluruh guru dan karyawan yang meliputi perencanaan program supervisi akademik; pelaksanaan supervisi akademik terhadap guru; menindaklanjuti hasil supervisi. Melalui beberapa indikator tersebut, hasil penelitian menunjukkan bahwa kompetensi supervisi kepala madrasah masuk kategori cukup dengan terata skor mencapi 3.7. Hasil ini sekaligus menggambarkan bahwa kompetensi supervisi kepala madrasah telah memenuhi SNP namun belum mencapai kondisi ideal.

\section{d. Kompetensi Sosial Kepala Madrasab (MI dan MTs)}

Kompetensi sosial adalah segenap. kemampuan kepala madrasah dalam melakukan aktivitas sosial baik secara intern (sesama warga madrasah) maupun ekstern (dengan masayarakat luas), seperti kemampuan bekerjasama dengan berbagai pihak untuk kepentingan madrasah; kemampuan berpartisipasi dalam kegiatan sosial kemasyarakatan, memiliki kepekaan sosial terhadap orang atau kelompok lain. Melalui beberapa indikator tersebut, hasil penelitian menunjukkan bahwa kompetensi sosial kepala madrasah masuk kategori baik dengan rerata skor mencapi 4.2. Hasil ini menunjukkan bahwa kompetensi sosial kepala madrasah telah memenuhi SNP dan telah mencapai kondisi ideal. Dari tujuh pernyataan, seluruh aspek telah mencapai kategori baik dengan rerata skor $80 \%$ keatas.

\section{e. Kompetensi Manajerial Kepala Madrasab (MI dan MTs).}

Kompetensi manajerial adalah segenap kemampuan yang dimiliki dalam mengelola madrasah yang meliputi kemampuan menyusun rencana 
madrasah; mengembangkan organisasi madrasah; memimpin madrasah; mengelola guru dan staf; mengelola perubahan dan pengembangan madrasah; menciptakan budaya dan iklim madrasah yang kondusif; mengelola sarana prasarana; mengelola hubungan dengan masyarakat; mengelola peserta didik dalam (penerimaan, penempatan dan pengembangan); mengelola pengembangan kurikulum dan kegiatan pembelajaran; mengelola keuangan secara akuntabel, transparan dan efisien; mengelola ketatausahaan; mengelola sistem informasi; memanfaatkan kemajuan teknologi dan melakukan monitoring, evaluasi dan pelaporan pelaksanaan program. Melalui beberap indikator tersebut, hasil penelitian menunjukkan bahwa kompetensi manajerial kepala madrasah masuk kategori kurang baik dengan rerata skor mencapi 3.2. Hasil ini menunjukkan bahwa kompetensi manajerial kepala madrasah telah mencapai kondisi ideal sesuai standar kompetensi kepala madrasah.

\section{Deskripsi Kesiapan Pengawas Menurut SNP}

Sesuai Permendiknas No. 12 tahun 2007, pengawas harus memiliki kualifikasi dan kompetensi memadai.

\section{Kualifikasi Pengawas (MI dan MTs)}

Dilihat dari kualifikasinya, hasil penelitian menunjukkan bahwa kualifikasi pengawas madrasah telah memenubi SNP. Melalui sembilan indikator yaitu kepangkatan dan golongan; usia saat diangkat jadi pengawas; diklat kepengawasan; pendidikan jabatan; seleksi tes penerimaan; jenjang pendidikan; sertifikasi pendidik; sertifikasi pengawas; pengalaman jadi guru dan pengalaman jadi kepala, empat diantaranya yaitu pendidikan jabatan; seleksi tes penerimaan; sertifikasi pendidik dan pengawas, belum memenuhi kualifikasi untuk diangkat jadi pengawas.

\section{Kompetensi Pengawas (MI dan MTs)}

Kompetensi pengawas yang dilihat elalui 5 indikator yaitu kompetensi kepribadian, supervisi manajerial, supervisi akademik, evaluasi pendidikan, penelitian pengembangan dan sosial, hasilnya penelitian menunjukkan bahwa kompetensi pengawas masuk kategori cukup dengan rerata skor mencapai 3.6. Hasil ini menunjukkan bahwa kompetensi pengawas telah memenubi SNP namun belum mencapai kondisi ideal. Kelemahan kompetensi pengawas terlihat pada kemampuannya melakukan supervisi manajerial dan pengembangan penelitian. Pada kedua kompetensi ini pengawas belum memenuhi SNP, karena rerata skor hanya mencapai 
3.1 dan 3.2. Namun, empat kompetensi lain, yaitu kepribadian; supervisi akademik; evaluasi pendidikan dan sosial telah memenuhi SNP.

\section{PENUTUP}

\section{A. Kesimpulan}

Penelitian tentang Kesiapan Madrasab dalam Pemenuhan Standar Layanan Minimal Pendidikan (Kesiapan Pendidik dan Tenaga Kependidikan Menurut SNP)" yang dilakukan di enam daerah, secara umum hasilnya menunjukkan bahwa madrasah telah memiliki kesiapan dalam memenuhi standar layanan minimal pendidikan (pendidik dan tenaga kependidikan menurut SNP). Namun kesiapan yang dimiliki tersebut belum mencapai kondisi ideal atau belum maksimal, karena masih terdapat kelemahankelemahan pada beberapa komponen, baik pada komponen pendidik/ guru, kepala maupun pengawas.

Pada komponen pendidik, hasil penelitian memperlihatkan bahwa kualifikasi guru (MI dan MTs) tersebut telah memenubi kualifikasi sesuai $S N P$, namun belum mencapai kondisi ideal. Karena dari empat indikator yaitu pendidikan formal, diklat kependidikan, keahlian khusus dan sertifikasi keguruan, satu diantaranya yaitu keahlian khusus belum memenuhi kualifikasi. Sedangkan kompetensi guru yang dilihat melalui empat kompetensi yaitu kompetensi paedagogik, profesional, sosial dan kepribadian, hasilnya menunjukkan bahwa kompetensi guru (MI dan MTs) masuk kategori cukup dengan rerata skor mencapai 3.9. Ini berarti bahwa kompetensi guru telah memenubi SNP, namun belum mencapai kondisi ideal, karena dari empat kompetensi tersebut, satu diantaranya yaitu kompetensi profesional belum memenuhi standar kompetensi sesuai dengan SNP.

Pada komponen kepala, hasil penelitian menunjukkan bahwa kualifikasi kepala (MI dan MTs) telab memenubi SNP, namun belum mencapai kondisi ideal, karena $t$ dari lima indikator kualifikasi yang dilihat yaitu pangkat/golongan, usia saat diangkat jadi kepala, pengalaman menjadi guru, jenjang pendidikan, sertifikasi keguruan serta sertifikasi kepala, dua diantaranya yaitu sertifikasi keguruan dan sertifikasi kepala belum memenuhi kualifikasi. Sedangkan kompetensi kepala madrasah yang dilihat melalui lima kompetensi yaitu kompetensi kepribadian; manajerial; kewirausahaan; supervisi dan sosial, hasilnya menunjukkan bahwa kompetensi kepala (MI dan MTs) masuk kategori cukup dengan rerata skor mencapai 3.8. Ini berarti bahwa kompetensi kepala (MI 
dan MTs) telab memenubi SNP, namun belum mencapai kondisi ideal, karena dari lima kompetensi tersebut, satu diantaranya yaitu kompetensi manajerial belum memenuhi standar kompetensi sesuaiSNP.

Pada komponen pengawas, dilihat dari kualifikasinya, juga telab memenubi SNP, namun belum mencapai kondisi ideal, karena masih ada beberapa indikator kompetensi yaitu diklat kepengawasan; pendidikan jabatan; seleksi tes penerimaan; jenjang pendidikan; sertifikasi pendidik dan sertifikasi pengawas; belum memenuhi kualifikasi sesuai dengan SNP. Sedangkan kompetensi pengawas yang dilihat melalui enam kompetensi yaitu kompetensi kepribadian; manajerial; supervisi akademik; evaluasi pendidikan; penelitian pengembangan dan sosial, hasilnya menunjukkan bahwa kompetensi pengawas masuk kategori cukup dengan rerata skor mencapai 3.6.

\section{B. Rekomendasi}

Mengingat masih banyaknya kelemahan madrasah dalam pemenuhan standar nasional pendidikan (pendidik dan tenaga kependidikan) pada beberapa komponen, baik pada komponen pendidik/guru, kepala maupun pengawas, perlu kiranya pemerintah (Departemen Agama melalui Dirjen Pendis) melakukan berbagai kebijakan yang mendukung madrasah untuk memenuhi SNP khususnya pada tiga komponen tersebut, dengan melihat dan memberikan skala prioritas pada beberapa kelemahankelemahan yang terjadi pada beberapa aspek khususnya pada tiga komponen pendidik dan tenaga kependidikan tersebut.

Untuk meningkatkan kualifikasi, sebaiknya dilakukan melalui berbagai diklat kependidikan, orientasi maupun kursus-kursus yang menunjang peningkatan keahlian para tenaga pendidik, sehingga memiliki keahlian khusus dalam menunjang tugasnya. Sedangkan untuk meningkatkan kompetensi, sebaiknya dilakukan melalui berbagai diklat kependidikan yang ada kaitannya dengan profesionalitasnya sebagai guru.

Untuk meningkatkan kualifikasi kepala, sebaiknya kebijakan Departemen Agama melalui Dirjen Pendis lebih terfokus pada pensertifikasian, baik sertifikasi keguruan maupun sertifikasi kepala, karena pada kedua indikator tersebut, kualifikasi kepala terlihat sangat lemah. Sedangkan untuk meningkatkan kompetensi kepala madrasah, sebaiknya dilakukan melalui berbagai diklat yang ada kaitannya dengan manajemen kepala madrasah. Karena kelemahan paling menonjol yang terjadi pada kepala madrasah adalah pada kompetensi manajerialnya. 


\section{SUMBER BACAAN}

Departemen Agama (2005): Data Satistik Madrasab.

Dirjen Kelembagaan Agama Islam (2003): Pedomon Pengembangan Administrasi dan Super-visi Pendidikan, Jakarta, Ditjen Kelembagaan Agama Islam Dep. Agama.

Hornby, AS (1982): Dictionary of Current English. Oxford University Press.

http:/ whwzgeocities.com/pengembangan-sekolah/http/www.geocities.com/pe ngembangan-sekolahindex.html, iakses tanggal 25 Pebruari 2008

Kamus Besar Babasa Indonesia, Departemen Pendidikan dan Kebudayaan Republik Indonesia, Perum Balai Pustaka, Jakarta, 1988.

Masykuri dkk. (2005): Profil Madrasah Tsanawiyal. Jakarta, Departemen Agama Rl, Ditjen Kelembagaan Agama Islam.

Moleong, Lexy.J (1990): Metodologi Penelitian Kkalitatif. Bandung, PT. Remaja Rosdakarya.

Mulyasa (2004): Kurikutum Berbasis Kompelensi (Konsep, Karakteristik dan Implementasi). Bandung, Remaja Rosdakarya.

PP No 14 Tahun 2005 tentang Guru dan Gosen.

PP. No. 19 tahun 2005 tentang Standar Nasional Pendidikan.

Purwanto, M. Ngalim (2005): Kinerja Pengawas Pendidikan Agama Islam. Jakarta, Puslitbang Pendidikan Agama dan Keagamaan.

Suara Merdeka, Selasa 21 Agustus 2007, Atasi Ketertinggalan Madrasab, 2000 guru madrasah dapat beasisiva

Sudjana, Nana (1995): Dasar-dasar Proses Belajar Mengajar., Bandung, Sinar Baru Algensindo.

Usman, Moh. Uzer (1995): Menjadi Guru Profesional. Bandung, PT. Remaja Rosdakarya.

UU No. 20 tahun 2003 tentng Sisdiknas

Wibowo, Alexander Jatmiko dan Tjiptono, Fandi (2002): Pendidikan Berbasis Kompetensi. Yogya karta, Universitas Atmajaya.

Wijaya, Cece dan A. Tabrani Rusyan (1994): Kemampuan Dasar Guru Dalam. Proses Belajar Mengajar. Bandung, PT. Remaja Rosdakarya.

Yatim, Badri dkk. (1999/2000): Sejarab Perkembangan Madrasab. Jakarta, Departemen Agama RI Dirjen Pembinaan Kelembagaan Agama Islan. 